PHARMACONJurnal IImiah Farmasi - UNSRAT Vol. 9 No. 1 FEBRUARI 2020 ISSN 2302 - 2493

\title{
REVIEW - PENGEMBANGAN KURKUMIN DAN ANDROGRAFOLIDA UNTUK SEDIAAN PARENTERAL
}

\author{
Karlah Lifie Riani Mansauda ${ }^{1)}$, Erladys Melindah Rumondor ${ }^{1}$ ) \\ 1) Program Studi Farmasi, FMIPA UNSRAT, Manado 95115
}

\begin{abstract}
Curcuma longa Linn (Kunyit) and Andrographis paniculata (Burm.f.) Nees (Sambiloto) are some examples of plants that grown in Indonesia that provides many health benefits with their isolated coumpound Curcumin and Andrographolide, respectively. However, due to their low watersolubility, low stability, rapid metabolism, poor absorption, and degradation during processing or within the gastrointestinal tract and alkaline conditions therefor reduces its oral bioavailability and consequently decreasing its development as a therapeutic drugs via oral. The advantage of parenteral route of administration including reduced toxicity, improved drug solubility and stability, prolonged circulation time, and enhanced tissue penetration. This review summarizes and discusses published journals on the key development on parenteral delivery system of curcumin and andrographolide as active ingredients.
\end{abstract}

Keywords : Curcumin, Andrographolide, Parenteral

\begin{abstract}
ABSTRAK
Curcuma longa Linn (Kunyit) dan Andrographis paniculata (Burm.f.) Nees (Sambiloto) adalah beberapa contoh tanaman yang tumbuh di Indonesia yang memberikan banyak manfaat kesehatan dengan senyawa yang terkandung didalamnya seperti Kurkumin dan Andrografolida. Namun karena sifatnya sukar larut dalam air, stabilitas rendah, metabolisme yang cepat, susah diabsorbsi, dan terdegradasi dalam asam lambung dan kondisi alkali, akibatnya menurunkan bioavailabilitas oralnya dan mengurangi manfaatnya. Pemberian secara parenteral adalah rute yang memiliki keuntungan termasuk mengurangi toksisitas, meningkatkan kelarutan obat dan stabilitas, memperpanjang waktu sirskulasi, dan peningkatan penetrasi jaringan. Ulasan ini merangkum dan membahas jurnal pada mengenai pengembangan sistem penghantaran secara parenteral dengan kurkumin dan andrografolida sebagai senyawa aktifnya.
\end{abstract}

Kata Kunci : Kurkumin, Andrografolida, Parenteral 


\section{PENDAHULUAN}

\begin{abstract}
Kurkumin dan andrografolida menarik perhatian karena memiiki keamanan dan efek farmakologis yang sangat baik. Kurkumin merupakan senyawa fenolik alami dari tumbuhan Curcuma longa Linn yang digunakan sebagai obat untuk pengobatan beberapa penyakit, seperti anoreksia, anti-bakteri, anti-proliferasi, antiinflamasi, antioksidan, anti-karsinogenik dan memiliki efek anti-amiloidogenik yang diuji secara in vitro dan in vivo (Mahmood et al., 2015).
\end{abstract}

Andrografolida merupakan senyawa diterpenoid yang diisolasi dari tanaman Andrographis paniculata (Burm.f.) Nees (Acanthaceae) atau biasa disebut dengan sambiloto dan digunakan sebagai obat tradisional di beberapa wilayah seperti Cina, Hong Kong, Filipina, Malaysia, Thailand, dan Indonesia (Hidalgo et al., 2013)

Kedua senyawa ini memiliki manfaat yang besar dalam pengobatan, akan tetapi aplikasinya terhambat karena sifat kelarutannya dalam air yang sangat rendah dan bioavailabilitas per oral yang buruk (Graverini et al., 2018; Yang et al., 2015) .

Pemberian secara parenteral merupakan salah satu rute penghantaran obat yang baik untuk senyawa aktif obat yang memiliki bioavailabilitas yang rendah dan memiliki indeks terapi yang sempit (Gulati dan Gupta, 2011). Pemberian secara parenteral meliputi subkutan, intramuscular, intravena, intradermal dan intraarteri. Perkembangan teknologi juga berpengaruh pada berkembangnya bentuk sediaan parenteral. Pengembangan formulasi sediaan parenteral termasuk pemberian obat koloid melalui rute parenteral seperti nanopartikel, niosom, liposom, polimer misel, dan bentuk in situ sistem pemberian obat secara parenteral (Hitesh, 2010). Sheikh et al (2011) dalam reviewnya menulis adanya potensi dari pengembangan formulasi sediaan parenteral dengan sistem pengiriman obat mukoadhesif seperti hidrogel, nanopatikulat untuk berbagai rute pemberian obat parenteral. Sekarang ini pengembangan sistem pemberian obat parenteral seperti sediaan yang dapat terbiodegradasi, obat kolodial seperti liposom, nanopartikel, injeksi depot intramuskular juga menjadi salah satu pilihan dalam penghantaran obat yang terus menerus, tertarget dan terkontrol kepada pasien (Gulati and Gupta, 2011).

Dalam review ini akan dibahas tentang pengembangan senyawa aktif alami kurkumin dan andrografolida yang memiliki bioavailabilitas buruk dan larut lemak dalam pemberiannya secara parenteral.

\section{KURKUMIN}

\section{A. Asal dan Manfaat Kurkumin}

Kurkumin, merupakan senyawa fenolik alami yang diisolasi dari rimpang dari tumbuhan Curcuma longa Linn (Kunyit), famili Zingiberaceae, yang telah digunakan ribuan tahun secara luas sebagai obat herbal diberbagai negara di Asia. Curcuminoid yang disebut juga diferuloylmethane adalah komponen utama dari Curcumin (77 wt\%), juga kedua kurkuminoid lainnya yaitu demethoxy curcumin (17 wt\%) dan bisdemethoxy curcumin (3 wt\%) (Mahmood et al., 2015).

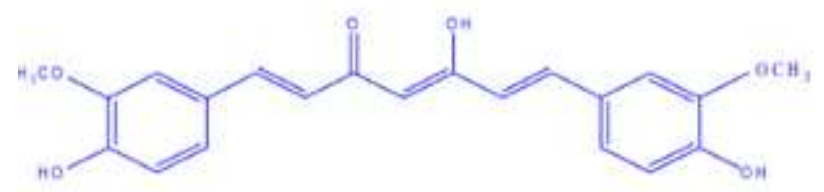

Gambar 1. Struktur Kurkumin (Mehanny et al., 2016)

Kurkumin digunakan sebagai obat tradisional untuk pengobatan beberapa penyakit, seperti anoreksia, keluhan pada empedu, batuk, penyakit pada hati, dan sinusitis. Beberapa studi juga mengungkapkan bahwa kurkumin memiliki sifat anti-bakteri, anti-proliferasi, anti- 
inflamasi, antioksidan, anti-karsinogenik dan efek anti-amyloidogenic yang diuji secara in vitro dan in vivo. Beberapa aktivitas biologi yang melibatkan kurkumin seperti anti-rematik, penyembuhan luka, antivirus, hepatoprotektif, dan anti-HIV (Mahmood et al., 2015).

\section{B. Pemberian Parenteral Kurkumin \\ 1. Pemberian Kurkumin Melalui Intravena (IV)}

Penelitian dari $\mathrm{Hu}$ et al (2016a), melarutkan kurkumin dalam Kolliphor dan alkohol dengan rasio 1:40:12 (w/w). Larutan kemudian ditambahkan saline. Hasilnya, formulasi injeksi kurkumin stabil dan tidak terdapat hemolisis terhadap darah kelinci yang diuji, dan tidak terjadi iritasi pada hewan uji kelinci. Hasil farmakokinetik terhadap formulasi ini juga menunjukkan peningkatan area under curve (AUC) dalam plasma (Hu et al., 2016a)

Enkapsulasi senyawa hidrofobik dalam misel juga telah dikembangkan karena memiliki keunggulan yang signifikan seperti meningkatkan kelarutan air, stabilitas dan distribusi (Kanai et al., 2011). Polimer misel dapat meningkatkan formulasi obat hidrofobik, memperpanjang waktu sirkulasi mereka dalam in vivo, meningkatkan serapan selular, dan secara pasif menargetkan pada daerah tumor dengan meningkatkan permeabilitas dan efek retensi (EPR) (Gong. et al. 2012). Ma et al 92008) telah mengembangkan amphiphilic misel kopolimer blok untuk PEO-PCL sebagai karir untuk kelarutan, stabilisasi, dan penghantaran Kurkumin yang dikendalikan. Namun, menurut Park et al. 2008 kristalisasi kuat dari poli ( $\varepsilon-$ kaprolakton) (PCL) menyebabkan ketidakstabilan pada misel. Hipotesis bahwa non-kristalisasi trimetilen karbonat (TMC) dalam kopolimer mungkin menghambat kristalisasi PCL untuk meningkatkan stabilitas pada misel. Untuk itu dalam rangka meningkatkan kelarutan air dan membuatnya tersedia untuk injeksi, Kurkumin dimuat ke dalam monomethyl poli (etilena glikol) -poly ( $\varepsilon$-kaprolakton) poly (trimetilen karbonat) (MPEG-P (CLco-TMC)) misel (Yang et al., 2015).

Yang et al (2015), Mengembangkan formulasi injeksi dan meningkatkan stabilitas kurkumin (Cur) untuk aplikasinya secara intravena untuk meningkatkan aktivitas antitumor sedangkan (Song et al., 2011) mengembangkan formulasi untuk menghambat pertumbuhan sel kanker prostat pada manusia dengan polimer misel.

Pada penelitian keduanya Kurkumin dimuat dalam misel MPEG-PCL-co-PDO dengan metode dispersi padat. Selain itu, kurkumin yang dimuat dalam misel menunjukkan stabilitas yang baik selama proses liofilisasi dan mudah untuk menyusun kembali (rekonstitusi) hanya dengan pengocokan manual. Tidak ada pemanasan atau sonikasi dibutuhkan dalam proses rekonstitusi ini. Liofilisasi kurkumin yang dimuat dalam misel benar-benar terdispersi dalam air. Selain itu, menunjukkan bahwa kurkumin yang dimuat dalam misel cukup stabil selama proses liofilisasi. Misel yang hanya dari MPEGPCL, apabila proses liofilisasi tanpa agen lyoprotective, sulit untuk terdispersi kembali dalam air tanpa pemanasan (Song et al., 2011).

\section{Pemberian Kurkumin Melalui Intramuskular (IM)}

Pemberian kurkumin secara intramuskular oleh dari (John et al., 2013) meneliti berbagai variasi kosolven seperti Nmethyl pyrrolidinone (NMP) $(15 \% \mathrm{v} / \mathrm{v})$, Tween $80(25 \% \mathrm{w} / \mathrm{v})$, etanol $(20 \% \mathrm{v} / \mathrm{v})$ dan air $(40 \% \mathrm{v} / \mathrm{v})$. Masing-masing kosolven diformulasikan dengan kurkumin dan hasil evaluasinya terhadap kelarutan dan bioavailabilitasnya dalam pemberian injeksi obat melalui intramuskular. Hasilnya, 
kelarutan kurkumin meningkat dengan penambahan kosolven NMP, etanol dan tween 80. Peningkatan yang signifikan kelarutan kurkumin dari $11 \mathrm{ng} / \mathrm{mL}$ menjadi $125 \mathrm{mg} / \mathrm{mL}$ terjadi pada penambahan kosolven NMP. Injeksi intramuskular pada tikus Sprague-Dawley menunjukkan pelepasan lepas lambat dari kurkumin dalam plasma dimana konsentrasi pada kurkumin lebih dari $240 \mathrm{ng} / \mathrm{mL}$ selama 4 jam. Hasil uji bioavailabilitas kurkumin dengan memakai kosolven meningkat hingga 28 kali daripada larutan kurkumin-DMSO.

Penelitian dari Wei et al, (2013) memformulasikan sediaan nanokristal kurkumin didekanoat (CurDD) menggunakan dengan metode wet ball milling kemudian nanokristal yang ada dibuat kedalam bentuk suspensi setelah dilakukan freeze-dry terlebih dahulu. Nanokristal kemudian ditambahkan peanut oil sehingga membentuk nanosuspensi dan dievaluasi farmakokinetik setelah pemberiannya melewati rute intramuskular. Kurkumin didekanoat adalah prodrug dari kurkumin yang digunakan dengan maksud memperpanjang efek terapetik kurkumin. Pembuatan nanokristal kurkumin didekanoat Hasilnya, formulasi nanokristal CurDD memiliki diameter $500 \mathrm{~nm}$,

\section{Pemberian Kurkumin Melalui Subkutan (SC)}

Penelitian tentang sediaan injeksi subkutan kurkumin oleh Ranjan et al., (2016) dilakukan formulasi dan karakterisasi nanopartikel kurkumin yang dienkapsulasi oleh polimer lipid DMPC (1,2dimyristoylsn- glycero-3-phosphocholine) and DMPG (1,2-dimyristoyl-sn-glycero-3phospho-rac-[1-glycerol]) dengan rasio (7:3) untuk terapi kanker paru-paru sel tidak kecil. Farmakokinetik formulasi nanopartikel kurkumin kemudian diukur dan dilakukan studi xenograft pada mencit yang membawa tumor A-549. Mencit diberi perlakuan injeksi subkutan formulasi nanopartikel kurkumin. Hasilnya, formulasi nanopartikel kurkumin memiliki ukuran \pm $90 \mathrm{~nm}$, dengan efisiensi enkapsulasi kirakira 93\%. Studi xenograft pada mencit menggambarkan efektivitas formulasi nanopartikel kurkumin secara signifikan menghambat pertumbuhan tumor setelah dilakukan pemberian secara subkutan.

Formulasi injeksi kurkumin yang dapat diberikan secara subkutan juga telah diteliti oleh Park et al, (2017) dimana formulasi sediaan kurkumin melibatkan carboxymethyl cellulose (CMC) dan chitosan (CHI) dalam proses cross-linking sehingga menghasilkan hidrogel yang kemudian diformulasikan menjadi mikrokapsul kurkumin. Larutan kemudian diinjeksikan secara subkutan pada mencit. Hasilnya, formulasi mikrokapsul kurkumin yang diuji secara in-vivo dapat mempertahankan senyawa aktif kurkumin dalam waktu lama karena adanya hidrogel yang terbentuk dari CMC dan CHI sehingga dapat memberikan efek depot (lepas lambat).

Efek lepas lambat senyawa kurkumin juga telah diteliti oleh Shahani et al (2010), yang memformulasi sediaan mikropartikel curcumin untuk injeksi. Formulasi menggunakan polimer poly(D,L-lactide-coglycolide) atau PGLA. Hasilnya mikropatikel kurkumin didapat memiliki diameter kira-kira $22 \mu \mathrm{m}$. Injeksi dilakukan melalui subkutan pada mencit, kurkumin terdeteksi dalam darah dan jaringan lain selama hampir sebulan.

\section{Pemberian Kurkumin Melalui Intradermal (ID)}

Pemberian secara Intradermal memiliki beberapa keuntungan diantaranya tidak menyebabkan rasa sakit, dan pemberiannya dapat dilakukan sendiri oleh pasien. Penelitian terbaru injeksi intradermal kurkumin dilakukan oleh Abdelghany et al, 
(2019) dimana nanosuspensi kurkumin ditambahkan kedalam microneedle poli (vinilalkohol) atau PVA dengan tinggi 900 $\mu \mathrm{m}$ dan diameter dasarnya $300 \mu \mathrm{m}$. Partikel nanosuspensi berukuran kira-kira $520 \mathrm{~nm}$. Mikroneedle kurkumin mampu berpenetrasi sedalam $500 \mu \mathrm{m}$, dan melebur di kulit dalam kurun waktu 60 menit. Senyawa aktif kurkumin kemudian bermigrasi ke lapisan kulit lebih dalam sampai $2300 \mu \mathrm{m}$. Hal ini menyatakan bahwa formulasi mikroneedle nanosuspensi kurkumin dapat menjadi salah satu cara untuk pemberian kurkumin secara intradermal.

\section{ANDROGRAFOLIDA}

\section{A. Asal dan Manfaat Andrografolida}

Andrografolida merupakan senyawa diterpenoid yang diisolasi dari tanaman Andrographis paniculata (Burm.f.) Nees (Acanthaceae) atau biasa disebut dengan sambiloto. Tanaman A. paniculata dapat ditemukan di India dan Indo-Cina dan digunakan sebagai obat tradisional di beberapa wilayah seperti Cina, Hong Kong, Filipina, Malaysia, Thailand, dan Indonesia. (Al Batran., 2013 ;Hidalgo et al., 2013)

Andrografolida merupakan salah satu dari senyawa lakton yang terdapat dalam Andrografolida paniculata, selain deoksiandrografolida, neoandrografolida, dan 14-deoksi-11-12-idehidroandrografolida (Akbar, S., 2011). Menurut Chen et al., (2010) andrografolida mudah larut dalam metanol, ethanol, akan tetapi sedikit larut dalam air.

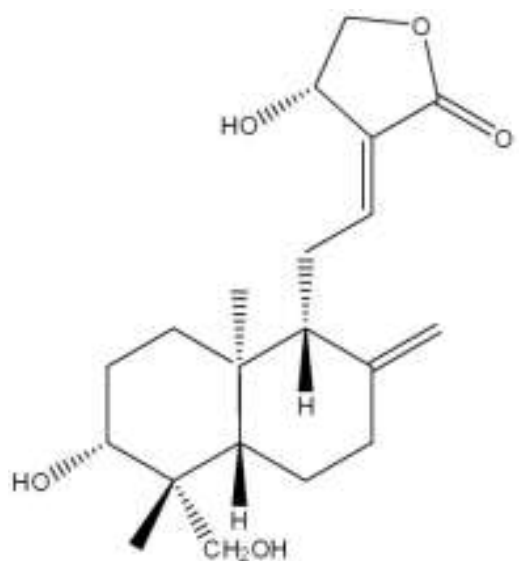

Gambar 2. Stuktur Andrografolida (Hidalgo et al., 2013)

Andrografolida merupakan senyawa aktif yang berguna sebagai antioksidan dan anti-inflamasi (Low et al., 2015), sebagai antibakteri terhadap bakteri Staphylococcus aureus, Streptococcus thermophiles, Bacillus subtilis, Escherichia coli, Mycobacterium smegmatis, Klebsiella pneumonia, dan Pseudomonas aeruginosa (Arifullah et al., 2013;Guan et al., 2013). Menurut penelitian Wintachai et al (2015), andrografolida berpotensi untuk menghambat replikasi virus chikungunya serta tidak memiliki efek samping yang berarti ketika diberikan pada manusia dengan dosis 1 sampai $2 \mathrm{mg} / \mathrm{kg} / \mathrm{hari}$ ( Melchior et al., 2000). Adrografolida juga diketahui memiliki kemampuan untuk menghambat pertumbuhan sel tumor dan mencegah perkembangan kanker (Varma et al., 2011).

Meskipun memiliki banyak manfaat akan tetapi senyawa adrografolida diketahui memiliki hambatan dalam memaksimalkan efek terapinya dikarenakan rendahnya bioavabilitas dan kelarutannya dalam air sehingga membatasi distribusi dan akumulasi senyawa di dalam tubuh. Adrografolida juga tidak stabil dalam gastrointestinal dan memiliki waktu patuh yang pendek (Casamonti et al., 2019). 


\section{B. Pemberian Andrografolida \\ 1. Pemberian Andrografolida Melalui Intravena (IV)}

Pengobatan terhadap penyakit memerlukan rute pemberian yang tepat untuk memaksimalkan efek terapinya. Andrografolida sendiri perlu diformulasikan dalam sediaan injeksi intravena untuk memaksimalkan efeknya. Formulasi nanosuspensi andrografolida merupakan salah satu solusi yang dikembangkan untuk mendapatkan terapi terhadapi inflamasi yang lebih selektif dan mampu meminimalisir toksisitas (Guo et al., 2017). Penelitian Guo et al (2017), memformulasikan injeksi nanosuspensi andrografolida menggunakan metode penggilingan basah dengan poloxamer 188 sebagai stabilisator non ionik dan sodium deoxycholate atau sodium tauroursodeoxy cholate sebagai stabilisator ionik. Hasilnya didapatkan nanosuspensi dengan ukuran $300 \mathrm{~nm}$ dan kelarutan andrografolida secara signifikan meningkat serta stabil secara fisik dan kimia dalam penyimpanan selama 6 bulan dengan penambahan manitol sebagai lioprotektan.

Formulasi vesikel surfaktan nonionik (niosom) untuk membawa adrografolida telah diteliti oleh $\mathrm{Tu}$ et al., (2013) untuk meningkatkan bioavailabilitas dan distribusinya pada jaringan tubuh. Formulasi niosome menggunakan span 60 dan kolesterol dengan metode hidrasi lapis tipis kemudian dilanjutkan dengan sonikasi untuk mengecilkan ukuran partikel niosom. Produk akhir niosom berukuran rata-rata $206 \mathrm{~nm}$, dengan efisiensi enkapsulasi sebesar $72 \%$. Studi farmakokinetik menunjukkan bahwa niosom meningkatkan bioavailabiltas adrografolida dan distribusi niosom dalam organ mengalami peningkatan serta memiliki potensi terapi obat tertarget khususnya organ hati.
Strategi untuk meningkatkan bioavailibilas adrografolida juga diteliti oleh (Graverini et al., 2017) dalam penelitiannya untuk meningkatkan kemampuan penetrasi adrografolida yang larut lemak untuk melewati sawar darah otak (blood brain barrier). Pada penelitian ini adrografolida diformulasikan kedalam nanopartikel lemak padat (solid lipid nanoparticle) yang dengan menggunakan lemak padat Comprotol 888 ATO dan surfaktan Brij 78. Evaluasi pada formulasi nanopartikel menyatakan bahwa formulasi memiliki efisiensi enkapsulasi sebesar 92\%, tidak mengalami perubahan dengan adanya serum albumin dan plasma dan setelah diinjeksikan melalui intravena pada tikus, formulasi nanopartikel adrografolida dapat dideteksi keberadaanya dalam otak tikus.

\section{Pemberian Andrografolida Melalui Intramuskular (IM)}

Formulasi adrografolida yang diinjeksikan secara intramuskular telah diteliti oleh Hu et al., (2016b) dengan tujuan untuk mengatasi rasa pahit dari adrografolida dan meningkatkan tingkat kepatuhan pemakaian obat pasien. Pada penelitian ini, nanosuspensi adrografolida yang paling baik didapat dengan menggunakan Tween 80 sebagai stabilisator. Metode yang digunakan yaitu penggilingan basah kemudian di evaluasi farmakokinetik intramuskular nanosuspensi adrografolida. Hasilnya, konsentrasi obat dalam plasma menunjukkan pelepasan lepas lambat adrografolida dan dideteksi terdapat dalam plasma hingga 28 hari. Pemerikasan uji iritasi menunjukkan bahwa formulasi aman dan dapat digunakan untuk pemberian melalui intramuskular.

Adrografolida juga telah diteliti potensinya sebagai obat lepas lambat dengan menggunakan Poly $(D, L$-lactide-coglycolide) (PLGA) untuk membentuk mikrosfer. Mikrosfer adrografolida 
diformulasikan untuk obat kemoterapi kanker. Hasilnya, mikrosfer berukuran kirakira $53 \mu \mathrm{m}$, efisiensi enkapsulasi sebesar $75 \%$ dan drug loading sebesar sekitar $47 \%$. Setelah diinjeksikan secara intramuskular konsentrasi adrografolida dalam plasma bertahan hingga lebih dari 1 minggu dan pelepasan adrografolida bersifat lepas lambat.

\section{Pemberian Andrografolida Melalui Subkutan (SC)}

Penelitian yang dilakukan oleh Sulaiman et al., (2010) bertujuan untuk mengevaluasi aktivitas antinosiseptif dan antiedematogenik adrografolida yang diberikan kepada hewan uji secara subkutan. Kristal adrografolida dilarutkan dalam larutan dimetil sulfoksida (DMSO) terlebih dahulu sebelum diuji. Dosis yang dipakai adalah 10,25 dan $50 \mathrm{mg} / \mathrm{kg}$ BB mencit. Hasil uji menunjukkan adanya aktifitas antinosiseptif dan antiedematogenik pada adrografolida yang berguna untuk menghilangkan rasa sakit dan mengobati inflamasi.

\section{KESIMPULAN}

Beberapa senyawa aktif yang berasal dari tanaman telah dilaporkan berpotensi untuk dikembangkan sistem pemberiannya secara parenteral untuk meningkatkan sistem penghantaran. Dua senyawa aktif tersebut adalah kurkumin dan andrografolida. Kurkumin merupakan senyawa aktif yang ulasan pembahasan pengembangannya dapat diberikan melalui intravena (IV), intramuscular (IM), subkutan (SC), dan Intradermal (ID) sedangkan untuk senyawa Andrografolida dapat diformulasikan untuk pemberian melalui intravena(IV), intramuskular (IM), dan subkutan (SC).

\section{SARAN}

Perkembangan teknologi memungkinkan formulasi Kurkumin dan Adrografolida untuk diberikan secara parenteral. Hal ini dapat menjadi dasar penelitian lebih lanjut terhadap pemilihan eksipien, stabilitas formulasi sediaan dan manfaat serta efek samping aplikasinya pada manusia.

\section{DAFTAR PUSTAKA}

Abdelghany, S., Tekko, I. A,, Vora, L., Larrañeta, E., Permana, A.D, dan Donnelly, R.F, 2019. NanosuspensionBased Dissolving Microneedle Arrays for Intradermal Delivery of Curcumin. Pharmaceutics, 11(7):308-320.

Al Batran, R., Al-Bayaty, F., Al-Obaidi, M. M., \& Abdulla, M. A. (2013). Acute toxicity and the effect of andrographolide on Porphyromonas gingivalis-induced hyperlipidemia in rats. BioMed Research International 2013(6):1-7.

Arifullah, M., Namsa, N. D., Mandal, M., Chiruvella, K. K., Vikrama, P., dan Gopal, G. R. 2013. Evaluation of anti-bacterial and anti-oxidant potential of andrographolide and echiodinin isolated from callus culture of Andrographis paniculata Nees. Asian Pacific journal of tropical biomedicine, 3(8):604-610

Casamonti, M., Risaliti, L., Vanti, G., Piazzini, V., Bergonzi, M. C., dan Bilia, A.R. 2019. Andrographolide Loaded in Micro- and Nano-Formulations: Improved Bioavailability, Target-Tissue Distribution, and Efficacy of the "King of Bitters" Engineering, 5(1): 69 -75

Chen, M., Xie, C., dan Liu, L. 2010. Solubility of Andrographolide in Various Solvents from $(288.2$ to 323.2$) \circ \mathrm{K}$. Journal of Chemical and Engineering Data, 55(11):5297-5298.

Gong, C., Wang, C., Wang, Y., Wu, Q., Zhang, D., Luo, F., dan Qian, Z. 2012. Efficient inhibition of colorectal peritoneal 
PHARMACONJurnal IImiah Farmasi - UNSRAT Vol. 9 No. 1 FEBRUARI 2020 ISSN 2302 - 2493

carcinomatosis by drug loaded micelles in thermosensitive hydrogel composites. Nanoscale, 4(10):3095-3104

Graverini, G., Piazzini, V., Landucci, E., Pantano, D., Nardiello, P., Casamenti, F., Pellegrini-Giampietro, D., Bilia, A., dan Bergonzi, M. 2017. Solid lipid nanoparticles for delivery of andrographolide across the blood-brain barrier: in vitro and in vivo evaluation. Colloids and surfaces. B, Biointerfaces. 161:302-313.

Guan, S. P., Tee, W., Ng, D. S., Chan, T. K., Peh, H. Y., Ho, W. E., Cheng, C., Mak, J. C., dan Wong, W. S. 2013. Andrographolide protects against cigarette smoke-induced oxidative lung injury via augmentation of Nrf2 activity. British journal of pharmacology, 168(7): 17071718.

Gulati, N., dan Gupta, H. 2011. Parenteral drug delivery: A review. Recent Patents on Drug Delivery and Formulation,. 5(2), 133-145.

Guo, L, Kang, L., Liu, X., Lin, X., Di, D., Wu, Y., Kong, D., Deng, Y., dan Song. Y. 2017. A novel nanosuspension of andrographolide: Preparation, characterization and passive liver target evaluation in rats. European Journal of Pharmaceutical Sciences, 104(1):13-22.

Hidalgo, M. A., Hancke, J. L., Bertoglio, J. C., dan Burgos, R. A. 2013. Andrographolide a new potential drug for long term treatment of rheumatoid arthritis disease. Dalam: Matsuno H., editor. Innovative Rheumatology. InTech; Croatia. Hal 247270

Hitesh B. 2010. A prolonged release parenteral drug delivery system - an overview. International Journal of Pharmaceutical Sciences Review and Research. 3(1): 1-11
Hu, L., Zhao, N., Zhang, J., Shi, Y., Hu, Q., Jiao, Y., Xiong, X., dan Su, J. 2016. Novel Curcumin Intravenous Injection System: Preparation,Characterization, Improved Bioavailability and Safety In Vitro and In Vivo. Research \& Reviews in Pharmacy and Pharmaceutical Science. 5(4): 23-30

Hu, L., Yang, C., Kong, D., Hu, Q., Gao, N., dan Zhai, F. 2016. Development of a longacting intramuscularly injectable formulation with nanosuspension of andrographolide. Journal of Drug Delivery Science and Technology, 35(1): 327-332.

John, M. K., Xie, H., Bell, E. C, dan Liang, D. 2013. Development and Pharmacokinetic Evaluation of a Curcumin Co-solvent Formulation. Anticancer Research, 33(10): 4285-4292.

Kanai, M., Yoshimura, K., Asada, M., Imaizumi, A., Suzuki, C., Matsumoto, S., Nishimura, T., Mori, Y., Masui, T., Kawaguchi, Y., Yanagihara, K., Yazumi, S., Chiba, T., Guha, S., dan Aggarwal, B. B. 2011. A phase I/II study of gemcitabine-based chemotherapy plus curcumin for patients with gemcitabineresistant pancreatic cancer. Cancer Chemotherapy and Pharmacology. 68(1): $157-64$

Low, M., Khoo, C. S., Münch, G., Govindaraghavan, S., dan Sucher, N. J. 2015. An in vitro study of antiinflammatory activity of standardised Andrographis paniculata extracts and pure andrographolide. BMC complementary and alternative medicine, 15(18):1-9.

Ma, Z., Haddadi, A., Molavi, O., Lavasanifar, A., Lai, R. dan Samuel, J. 2008. Micelles of poly(ethylene oxide)-b-poly(epsiloncaprolactone) as vehicles for the solubilization, stabilization, and controlled delivery of curcumin, Journal of 
PHARMACONJurnal Ilmiah Farmasi - UNSRAT Vol. 9 No. 1 FEBRUARI 2020 ISSN 2302 - 2493

Biomedical Materials Research Part A, 86(2):300-310

Mahmood, K., Zia, K. M., Zuber, M., Salman, M., dan Anjum, M. N. 2015. Recent developments in curcumin and curcumin based polymeric materials for biomedical applications: A review. International Journal of Biological Macromolecules, 81(1):877-890.

Melchior, J., Spasov, A.A., Ostrovskij, O.V., Bulanov, A.E, dan Wikman, G. 2000. Double-blind, placebo-controlled pilot and phase III study of activity of standardised Andrographis paniculata Herba Nees extract fixed combination (Kan jang) in the treatment of uncomplicated upperrespiratory tract infection. Phytomedicine. 7(5):341-350.

Park, S. H., Choi, B. G., Joo, M. K., Han, D. K., Sohn, Y.S., dan Jeong, B. 2008. Temperature-sensitive poly (caprolactoneco-trimethylene carbonate)-poly(ethylene glycol)-poly(caprolactoneco- trimethylene carbonate) as in situ gel-forming biomaterial. Macromolecules, 41(17): 6486-6492.

Park,S., Kim, D., Panta, P., Heo, J. Y., Lee, H. Y., Kim, J. H., Min, B. H., dan Kim, M. S. 2017. An intratumoral injectable, electrostatic, cross-linkable curcumin depot and synergistic enhancement of anticancer activity. NPG Asia Mater, 9(1): $1-14$

Ranjan, A.P., Mukerjee, A., Gdowski, A., Helson, L., Bouchard, A., Majeed, M., dan Vishwanatha, J. K. 2016. Curcumin-ER prolonged subcutaneous delivery for the treatment of non-small cell lung cancer. Journal of Biomedical Nanotechnology, 12(4):679-88.

Shahani, K., Swaminathan, S. K,, Freeman, D., Blum, A., Ma, L., dan Panyam, J. 2010. Injectable sustained release microparticles of curcumin: a new concept for cancer chemoprevention. Cancer Research. 70(11):4443-4452

Sheikh, R, Rajsingh T. R, Garland, M. J, Woolfson, A. D, dan Donelly, R. F. 2011. Mucoadhesive drug delivery system. Journal of Pharmacy and Bioallied Sciences; 3(1): 89-100.

Song, L., Shen, Y., Hou, J., Lei, L., Guo, S., dan Qian, C. 2011. Polymeric micelles for parenteral delivery of curcumin: Preparation, characterization and in vitro evaluation. Colloids and Surfaces A: Physicochemical and Engineering Aspects, 390(1): 25-32.

Sulaiman, M. R., Zakaria, Z. A., Abdul Rahman, A., Mohamad, A. S., Desa, M. N., Stanslas, J., Moin,S., dan Israf, D. A .2010. Antinociceptive and Antiedematogenic Activities of Andrographolide Isolated From Andrographis paniculata in Animal Models, Biological Research For Nursing, 11(3);293-301.

Tu, Y., Sun, D., Zhang, J., Jiang, Z., Chen, Y., Zeng, X., Huang, D., dan Yao, N. 2013. Preparation and characterisation of andrographolide niosomes and its antihepatocellular carcinoma activity. Journal of microencapsulation. 31(4):307-316.

Varma, A., Padh, H., dan Shrivastava, N. 2011. Andrographolide: a new plantderived antineoplastic entity on horizon. Evidence-based complementary and alternative medicine : eCAM. 2011:1-9

Wei, X. L., Han, Y. R., Quan, L. H., Liu, C. Y., dan Liao, Y.H. 2013. Oily nanosuspension for long-acting intramuscular delivery of curcumin didecanoate prodrug: preparation, characterization and in vivo evaluation. European journal of pharmaceutical sciences: official journal 
PHARMACONJurnal IImiah Farmasi - UNSRAT Vol. 9 No. 1 FEBRUARI 2020 ISSN 2302 - 2493

of the European Federation for Pharmaceutical Sciences, 49(2):286-293.

Wintachai, P., Kaur, P., Lee, R. C., Ramphan, S., Kuadkitkan, A., Wikan, N., Ubol, S., Roytrakul, S., Chu, J.J., dan Smith, D.R. 2015. Activity of andrographolide against chikungunya virus infection. Scientific Reports, 5; 1-14;

Yang, X., Li, Z., Wang, N., Li, L., Song, L., He, T.,Gong, C. 2015. Curcumin-encapsulated polymeric micelles suppress the development of colon cancer in vitro and in vivo. Scientific Reports, 5:10322 . 